\title{
Aktivitas antibakteri ekstrak kulit buah kakao (Theobroma cacao L.) terhadap Escherichia coli, Bacillus subtilis, dan Staphylococcus aureus
}

\author{
Antibacterial activity of cocoa pod husk extract (Theobroma cacao L.) against \\ Escherichia coli, Bacillus subtilis, and Staphylococcus aureus \\ Agustin Sri MULYATNI*), Asmini BUDIANI \& Darmono TANIWIRYONO \\ Balai Penelitian Bioteknologi Perkebunan Indonesia, Jalan Taman Kencana No.1 Bogor 16151, Indonesia
}

Diterima tanggal 20 September 2012/disetujui tanggal 6 Nopember 2012

\begin{abstract}
Cocoa (Theobroma cacao L.), one of the most important export commodities from Indonesia, is widely planted with current total area of 1.6 million $\mathrm{Ha}$, producing 500.000 metric tons of dry bean in 2011. At the time of harvest, instead of seed approximately the same volume cacao husk is produced. The aim of the study was to assess the potential of cocoa husk extract as an antibacterial against Escherichia coli, Bacillus subtilis, and Staphylococcus aureus, and to determine the minimum inhibitory concentration (MIC) of cocoa husk extract to the three test bacteria. Extraction of cocoa husk conducted by maceration method using ethanol 96\%. Analysis of antibacterial activity was done by paper disc diffusion method. Completely Randomized Design of single factor presentage that is extract concentration of $0 ; 1 ; 2 ; 4 ; 8 ; 16 ; 32$; and $64 \%(\mathrm{~g} / \mathrm{mL})$ with three replicans were applied.The results showed that the extract of cocoa pod husk has antibacterial activity against $\mathrm{S}$. aureus, $\mathrm{B}$. subtilis, and $\mathrm{E}$. coli with the MIC are $8 \%(\mathrm{~g} / \mathrm{mL}), 16 \%(\mathrm{~g} / \mathrm{mL})$, and $32 \%(\mathrm{~g} / \mathrm{mL})$ respectively.
\end{abstract}

[Keywords : Antibacteria, cocoa pod-husk, ethanol, alkaloid compound, flavonoid]

\begin{abstract}
Abstrak
Kakao (Theobroma cacao L.), salah satu komoditi ekspor terpenting Indonesia, ditanam secara luas dengan total luasan 1,6 juta Ha, menghasilkan 500.000 ton biji kering pada tahun 2011. Di samping biji sebagai hasil utama, pada saat panen juga dihasilkan kulit buah dengan volume yang hampir sama dengan biji. Penelitian ini bertujuan untuk mengkaji potensi ekstrak kulit buah kakao sebagai antibakteri terhadap Escherichia coli, Bacillus subtilis, dan Staphylococcus aureus serta menentukan konsentrasi hambat minimum (KHM) ekstrak kulit buah kakao terhadap ketiga bakteri uji. Ekstraksi kulit buah kakao dilakukan dengan metode Maserasi menggunakan pelarut etanol 96\%. Analisis aktivitas antibakteri dilakukan dengan metode difusi cakram kertas. Penelitian ini menggunakan Rancangan
\end{abstract}

Acak Lengkap (RAL) dengan faktor tunggal konsentrasi ekstrak, yaitu $0 ; 1 ; 2 ; 4 ; 8 ; 16 ; 32$; dan $64 \%(\mathrm{~g} / \mathrm{mL})$, masing-masing dengan tiga kali ulangan. Hasil penelitian menunjukkan bahwa ekstrak kulit buah kakao berpotensi sebagai antibakteri terhadap $S$. aureus, B. subtilis dan E. coli, dengan KHM berturut-turut adalah $8 \%(\mathrm{~g} / \mathrm{mL})$, $16 \%(\mathrm{~g} / \mathrm{mL})$, dan $32 \%(\mathrm{~g} / \mathrm{mL})$.

[Kata kunci: Antibakteri, kulit-buah kakao, ethanol, senyawa alkoloid, flavonoid]

\section{Pendahuluan}

Kakao (Theobroma cacao L.) merupakan salah satu komoditi ekspor negara Indonesia dengan nilai jual yang cukup tinggi. Kementerian Pertanian melaporkan bahwa pada tahun 2010 Indonesia menempati urutan ke-3 sebagai negara penghasil kakao terbesar di dunia dengan total ekspor sebesar 900 ribu ton (Anonim, 2010). Pada saat panen, umumnya petani memanen biji kakao untuk diolah menjadi cokelat, dan menghasilkan limbah kulit buah kakao yang cukup banyak. Keberadaan limbah tersebut sering kali tidak dimanfaatkan secara baik dan kadang dibiarkan begitu saja menjadi sampah pertanian. Limbah kulit buah kakao yang dihasilkan dalam jumlah banyak akan menjadi masalah jika tidak ditangani dengan baik karena produksi limbah padat ini mencapai lebih dari $60 \%$ dari total produksi buah (Harsini \& Susilowati, 2007). Beberapa teknologi telah dikembangkan untuk mengolah kulit buah kakao menjadi pakan ternak, kompos, dan produk lain, tetapi masih diperlukan teknologi lain untuk dapat memanfaatkannya lebih optimal (Adamafio et al., 2004; Alemawor et al., 2009).

Beberapa bakteri dapat menyebabkan timbulnya penyakit pada manusia. Bakteri E. coli dapat menyebabkan penyakit diare, dan $S$. aureus dapat menyebabkan penyakit kulit dan infeksi saluran 
pernafasan seperti sinusitis. Secara alami kedua bakteri ini merupakan bakteri flora normal pada tubuh manusia, tetapi bila populasinya tinggi dan keberadaannya di luar habitat aslinya maka kedua bakteri tersebut berpotensi untuk menimbulkan penyakit (Brooks et al, 2001). Kedua bakteri tersebut memproduksi enterotoksin yang dapat mencemari makanan, terutama makanan yang mengandung protein, sehingga mengakibatkan keracunan (Pratiwi, 2008). Bakteri Bacillus subtilis merupakan kontaminan di udara yang tidak berbahaya, akan tetapi keberadaanya dapat menyebabkan kerusakan pada makanan khususnya makanan kaleng, sehingga muncul gejala gastroenteritis pada manusia (Talaro, 2002).

Kulit buah kakao diketahui mengandung senyawa aktif alkaloid yaitu theobromin (3,7dimethylxantine). Salah satu efek dari theobromin adalah sebagai penenang, sehingga zat tersebut menjadi faktor pembatas pada pemakaian limbah kulit buah kakao sebagai pakan ternak (Helmestein, 2010). Kulit buah kakao mengandung senyawa aktif flavonoid atau tanin terkondensasi atau terpolimerisasi, seperti antosianidin, katekin, dan leukoantosianidin yang banyak terikat dengan glukosa. Senyawa-senyawa bioaktif tersebut diketahui memiliki sifat antibakteri (Matsumoto et.al, 2004). Keberadaan senyawa tersebut di dalam kulit buah kakao diduga menjadi salah satu penyebab tidak ditemukannya penyakit pada tanaman kakao yang disebabkan oleh bakteri. Penelitian mengenai potensi ekstrak kulit buah kakao jenis lindak (Forastero) telah dilakukan oleh Sartini et al. (2007). Hasil penelitian menunjukkan bahwa ekstrak kulit buah kakao dapat menghambat pertumbuhan bakteri Staphylococcus aureus, Streptococcus mutan, Escherichia coli, dan Salmonella thyposai dengan tingkat konsentrasi yang berbeda. Bakteri uji yang paling rentan adalah Streptococcus mutan. Meskipun demikian aktivitas antibakteri dari ekstrak kulit buah kakao masih perlu dilakukan lebih mendalam. Tujuan penelitian ini untuk menguji aktivitas antibakteri ekstrak kulit buah kakao jenis hibrida secara in vitro terhadap E.coli, S. aureus, dan B. subtilis.

\section{Bahan dan Metode}

Penelitian ini dilaksanakan di Laboratorium Mikroba dan Bioproses Balai Penelitian Bioteknologi Perkebunan Indonesia (BPBPI), Bogor, Jawa Barat. Bahan yang digunakan adalah kulit buah kakao jenis Hibrida (Upper Hibrida Amazon).

\section{Preparasi ekstrak konsentrat kulit buah kakao}

Kulit buah kakao hibrida yang sudah masak diekstrak dengan metode Maserasi menggunakan pelarut etanol 96\% (Goeswin, 2007). Sebelum proses ekstraksi kulit buah kakao dikeringkan dan dihaluskan hingga menjadi serbuk halus. Sebanyak $40 \mathrm{~g}$ serbuk kulit buah kakao direndam dengan $400 \mathrm{~mL}$ etanol 96\% di dalam Erlenmeyer. Perendaman dilakukan dalam suhu ruang pada shaker dengan kecepatan 120 rpm secara kontinyu selama 24 jam. Penyaringan dilakukan dengan kertas saring Whatman no.41, sehingga diperoleh maserat. Pelarut (etanol) dalam maserat diuapkan menggunakan rotary evaporator sampai diperoleh ekstrak pekat dengan bobot konstan. Ekstrak pekat diambil 0,5 g kemudian diencerkan menjadi beberapa tingkatan konsentrasi, yaitu $1 ; 2 ; 4 ; 8 ; 16$; 32; dan 64\% (g/mL) (Das et al., 2010).

\section{Pemeriksaan senyawa alkaloid dan flavonoid}

Uji alkaloid pada penelitian ini dilakukan menggunakan pereaksi Bouchardat. Pereaksi tersebut dibuat dengan melarutkan $4 \mathrm{~g}$ kalium iodida ke dalam $20 \mathrm{~mL}$ akuades dan ditambahkan $2 \mathrm{~g}$ iodium kemudian dikocok sampai homogen. Volume pereaksi ditepatkan $100 \mathrm{~mL}$ dengan penambahan akuades (Anggriani, 2010). Sebanyak $2 \mathrm{~mL}$ ekstrak konsentrat kulit buah kakao ditambahkan $1 \mathrm{~mL}$ pereaksi Bouchardat dan dikocok. Alkaloid dianggap positif jika timbul endapan berwarna putih. Uji senyawa flavonoid dilakukan dengan cara menambahkan serbuk $\mathrm{Mg}$ dan $\mathrm{HCl}$ pekat ke dalam ekstrak konentrat kulit buah kakao. Apabila terbentuk warna orange, merah, atau kuning, berarti positif flavonoid. (Ditjen POM, 1995 dalam Anggriani, 2010).

\section{Uji aktivitas antibakteri}

Uji aktivitas antibakteri dilakukan dengan metode difusi agar. Suspensi bakteri uji (E coli, B. subtilis, S.aureus) sebanyak $1 \mathrm{~mL}$ dengan kerapatan terukur hasil Total Plate Count (TPC) dimasukkan ke dalam cawan petri dan ditambahkan Nutrient Agar. Kertas saring Whatman no. 41 berdiameter $1 \mathrm{~cm}$ dicelupkan pada cairan ekstrak hasil pengenceran beberapa konsentrasi dan pada akuades steril sebagai kontrol. Kertas saring tersebut diletakkan secara teratur di atas biakan cawan, diinkubasi pada suhu $37^{\circ} \mathrm{C}$ selama 24 jam dan kemudian dihitung diameter zona bening yang muncul di sekitar kertas saring dengan menggunakan penggaris (Das et al., 2010). 


\section{Penentuan konsentrasi hambat minimum (KHM)}

Berdasarkan diameter zona bening yang dihasilkan, selanjutnya ditentukan persentase konsentrasi ekstrak terkecil (Andrews, 2006). Parameter yang diamati adalah diameter zona bening yang terbentuk di sekitar kertas saring $(\mathrm{mm})$. Rancangan percobaan menggunakan Rancangan Acak Lengkap (RAL) faktor tunggal yaitu persentase konsentrasi ekstrak yang terdiri dari $0 \%$ (kontrol), $1 ; 2 ; 4 ; 8 ; 16 ; 32$; dan $64 \%$, $(\mathrm{g} / \mathrm{mL})$ masing-masing dengan tiga kali ulangan. Rancangan percobaan tersebut berlaku untuk masing-masing bakteri uji (Hanafiah, 2001).

Normalitas data yang diperoleh, diuji menggunakan uji statistik Kolmogorov-Smirnov dan data terdistribusi tidak normal dan tidak homogen, maka data dianalisis dengan menggunakan uji statistik non parametrik Kruskall-Wallis. Analisis selanjutnya dengan uji lanjut Mann-Whitney untuk mengetahui perbedaan diameter zona hambat yang bermakna pada masing-masing konsentrasi. Analisis statistik dilakukan dengan menggunakan Statistical Product and Service Solution (SPSS) versi 16.00 (Dahlan, 2004).

\section{Hasil dan Pembahasan}

\section{Aktivitas antibakteri ekstrak kulit buah kakao}

Hasil penelitian menunjukkan terjadinya penghambatan ekstrak kulit buah kakao terhadap pertumbuhan ketiga bakteri uji yang ditunjukkan dengan terbentuknya zona hambat di sekitar kertas cakram yang mengandung ekstrak kulit buah kakao (Gambar 1). Penghambatan pertumbuhan bakteri oleh ekstrak kulit buah kakao diduga berasal dari aktifitas senyawa bioaktif yang terlarut, di antaranya adalah senyawa alkaloid dan flavonoid. Hasil pemeriksaan fitokimia terhadap ekstrak menunjukkan hasil yang positif terdeteksi adanya senyawa alkaloid maupun senyawa flavonoid. (Gambar 2) Endapan berwarna putih menunjukkan adanya senyawa alkaloid. Dirjen POM (1995 dalam Anggriani, 2010) melaporkan bahwa alkaloid dianggap positif jika terjadi endapan ketika ekstrak direaksikan dengan salah satu dari pereaksi Dragendorf, Bouchardat, atau Mayer.

Pemeriksaan flavonoid menunjukkan hasil yang positif dengan terjadinya perubahan warna ekstrak menjadi kemerahan (Gambar 2) setelah ditambahkan dengan serbuk $\mathrm{Mg}$ dan $\mathrm{HCl}$ pekat (Arifin et al., 2006). Senyawa alkaloid merupakan senyawa organik yang memiliki atom nitrogen dan bersifat basa (alkali) dan dapat menyebabkan koagulasi protein sel bakteri, sehingga menyebabkan penghambatan pertumbuhan bakteri. Koagulasi protein akan mengganggu komponen penyusun peptidoglikan pada sel bakteri yang menyebabkan lapisan dinding sel tidak terbentuk secara utuh, sehingga menyebabkan kematian sel bakteri. Flavonoid pada ekstrak kulit kakao ter-masuk golongan senyawa fenolik yang mempunyai ikatan glikosida. Senyawa fenolik akan berinteraksi dengan protein membran sel bakteri melalui proses adsorbsi dengan cara terikat pada bagian hidrofilik membran sel. Senyawa fenolik selanjutnya akan masuk ke dalam membran sel dan menyebabkan presipitasi protein sel. Hal tersebut mengganggu permeabilitas membran sel, sehingga membran sel dapat mengalami lisis.

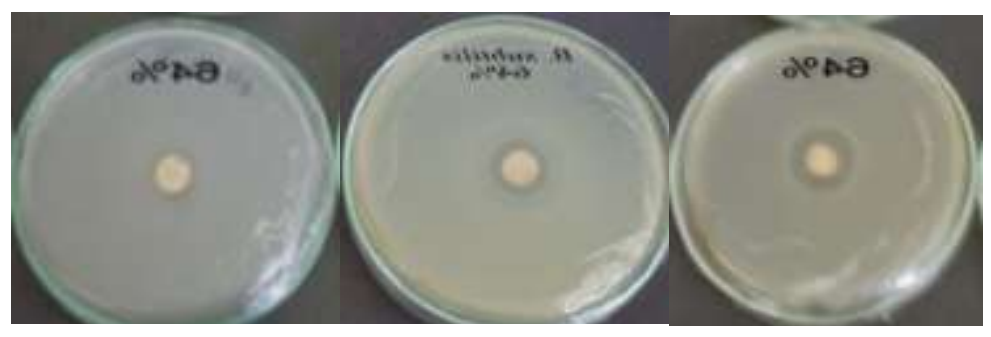

Gambar 1. Aktivitas antibakteri ekstrak kulit buah kakao pada konsentrasi 64\% terhadap pertumbuhan (a) E. coli, (b) B. subtilis, (c) S. aureus setelah inkubasi 24 jam .

Figure 1. Antibacterial activity of pod cacao extrac at a concentration $64 \%$ against (a) E. coli, (b) B. subtilis, (c) S. Aureus after 24 hours incubation. 
Hasil pengamatan aktivitas antibakteri ekstrak kulit buah kakao dengan konsentrasi 64\% terhadap biakan $E$. coli dan $S$. aureus, menunjuk-kan adanya daerah pertumbuhan bakteri yang lebih subur di sekitar zona hambat, sedangkan pada biakan $B$. subtilis menunjukkan adanya daerah pertumbuhan bakteri yang kurang subur di sekitar zona hambat (Gambar 1). Perbedaan daerah pertumbuhan di sekitar zona hambat tersebut, salah satunya karena adanya perbedaan permeabilitas membran sel bakteri. Membran sel bakteri bersifat selektif permeabel, dan setiap sel memiliki permeabilitas membran yang berbeda, karena perbedaan struktur membran sel dan enzim yang berfungsi dalam proses penyerapan nutrien. Kusumawati (2003) menyatakan bahwa perbedaan permeabilitas disebabkan karena keragaman struktur asam lemak membran sel bakteri, dan diduga mempengaruhi ketahanan sel bakteri. Kulit buah kakao diketahui mengandung unsur kalsium, fosfor, kalium, dan nitrogen (Sudirja et al., 2007). Unsur-unsur tersebut merupakan nutrien yang dibutuhkan mikroorganisme dalam jumlah yang relatif besar, yakni sebagai penyusun protein, kofaktor enzim dan sebagai kation seluler (Prescott, 2005). Pertumbuhan B. subtilis di sekitar zona hambat yang kurang subur, diduga karena adanya pengaruh senyawa aktif di daerah tersebut yang menyebabkan nutrien dari ekstrak yang berdifusi ke dalam medium tidak dapat diserap dengan baik oleh sel bakteri. Pertumbuhan bakteri dengan tingkat proloferasi yang tinggi di sekitar zona hambatan dimungkinkan juga sebagai respons bakteri untuk mematahkan pengaruh zat anti bakteri ekstrak konsentrat kulit buah kakao.

Hasil analisis statistik Kruskall-Wallis dan uji lanjut Mann-Whitney menunjukkan terdapat pengaruh nyata dari konsentrasi ekstrak terhadap aktivitas penghambatan masing-masing bakteri uji, yang ditandai dengan adanya perbedaan diameter zona hambat yang terbentuk. Gambar 3 menunjukkan bahwa ekstrak kulit buah kakao dapat menghambat pertumbuhan $E$. coli pada konsentrasi ekstrak $32 \%$ dan $64 \%$, dengan rerata diameter $3,00 \mathrm{~mm}$ dan $8,83 \mathrm{~mm}$. Analisis uji statistik menunjukkan bahwa diameter zona hambat pada kedua konsentrasi tersebut berbeda nyata, hal ini menunjukkan bahwa kedua konsentrasi ekstrak tersebut berpengaruh nyata terhadap aktivitas penghambatan E. coli Gambar 4 menunjukkan bahwa penghambatan pertumbuhan $B$. subtilis mulai pada konsentrasi ekstrak sebesar $16 \%$. Hambatan pertumbuhan paling besar terjadi pada konsentrasi $64 \%$ dengan rerata diameter 7,67 mm

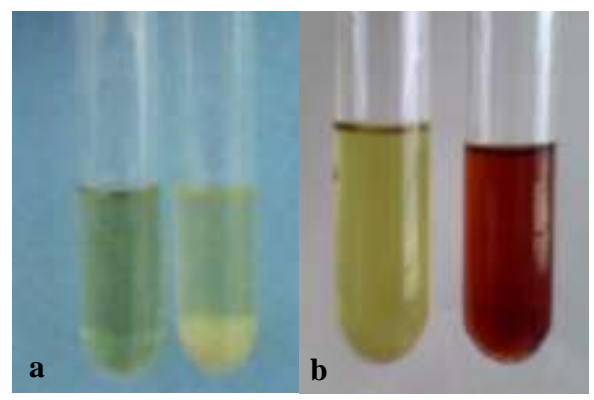

Gambar 2. Hasil pemeriksaan fitokimia (a) uji alkaloid, (b) uji flavonoid.

Figure 2. Phytochemical examination results (a)alkaloid test, (b) flavonoid test.

yang tidak berbeda nyata dengan penghambatan pada konsentrasi $32 \% \quad(6,50 \mathrm{~mm})$, dan kedua konsentrasi ekstrak tersebut berbeda nyata dengan perlakuan konsentrasi ekstrak lainnya.

Gambar 5 menunjukkan penghambatan ekstrak kulit buah kakao terhadap pertumbuhan $S$. aureus yang mulai terjadi pada konsentrasi ekstrak $8 \%$. Hambatan pertumbuhan yang paling besar terjadi pada konsentrasi $64 \%$ dengan rerata diameter zona hambat $10 \mathrm{~mm}$ yang berbeda nyata dengan perlakuan lainnya. Diameter zona hambat pada perlakuan konsentrasi $16 \%$ dan $32 \%$ tidak berbeda nyata, akan tetapi berbeda nyata dengan perlakuan lainnya yang berarti bahwa kedua konsentrasi ekstrak tersebut tidak berpengaruh nyata terhadap aktivitas penghambatan bakteri $S$. aureus, sedangkan konsentrasi ekstrak lainnya berpengaruh nyata.

Berdasarkan hasil uji aktivitas antibakteri ekstrak kulit buah kakao terhadap masing-masing bakteri uji, terbukti bahwa aktivitas penghambatan dipengaruhi oleh konsentrasi ekstrak pada kertas cakram. Aktivitas antibakteri semakin meningkat, dengan semakin tingginya konsentrasi ekstrak. Banyaknya kandungan senyawa aktif dalam ekstrak menyebabkan senyawa aktif akan lebih mudah untuk merusak sel bakteri. Selain itu senyawa aktif akan mampu menghambat pertumbuhan bakteri lebih banyak yang ditandai dengan terbentuknya zona hambat di sekitar kertas saring.

Tidak terbentuknya zona hambat pada beberapa perlakuan konsentrasi ekstrak (1\%, 2\%, 4\%), disebabkan oleh konsentrasi ekstrak yang rendah. Rendahnya senyawa aktif tersebut dapat menyebabkan penghambatan pertumbuhan masingmasing bakteri uji, terjadi pada sebagian kecil dari jumlah total sel bakteri, sehingga bakteri yang tidak terganggu oleh senyawa aktif dapat tumbuh. Hal ini ditandai dengan keruhnya daerah di sekitar kertas saring. 


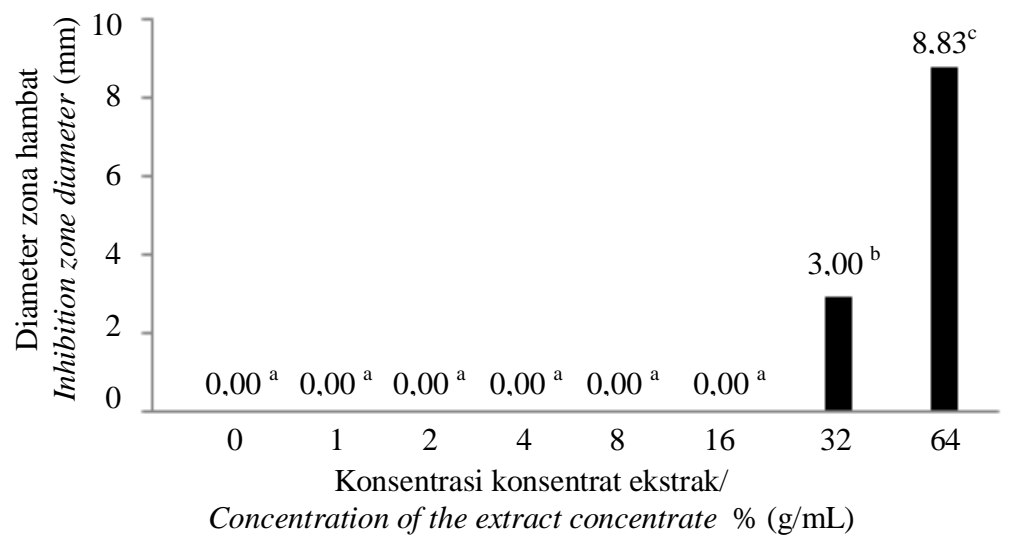

Gambar 3. Rerata diameter zona hambat dari ekstrak kulit buah kakao terhadap pertumbuhan bakteri E. coli pada inkubasi 24 jam.

Figure 3. The mean diameter of inhibition zone of cacao pod husk extract on the growth of E. coli at 24 hours incubation.

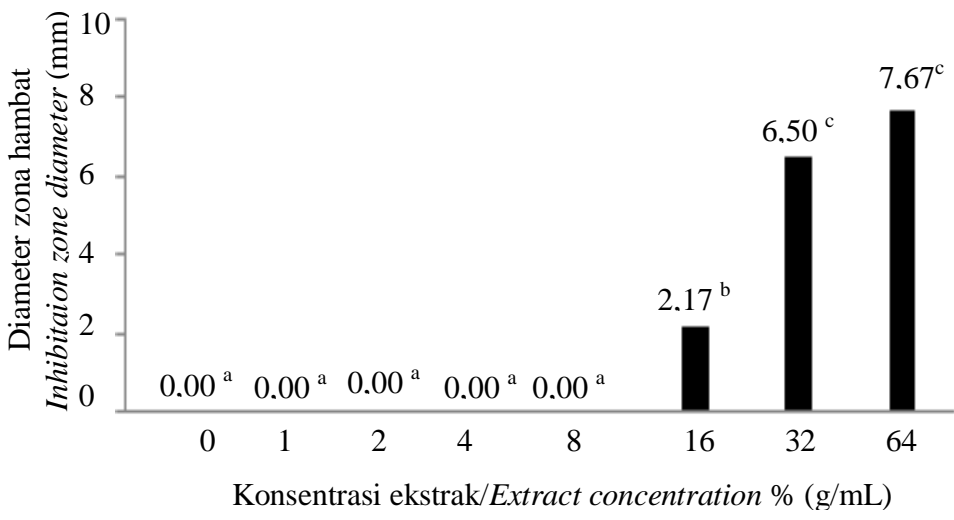

Gambar 4. Rerata diameter zona hambat dari ekstrak kulit buah kakao terhadap pertumbuhan bakteri $B$. subtilis pada inkubasi 24 jam.

Figure 4. The mean diameter of inhibition zone of cacao pod husk extract on the growth of B. subtilis at 24 hours incubation.

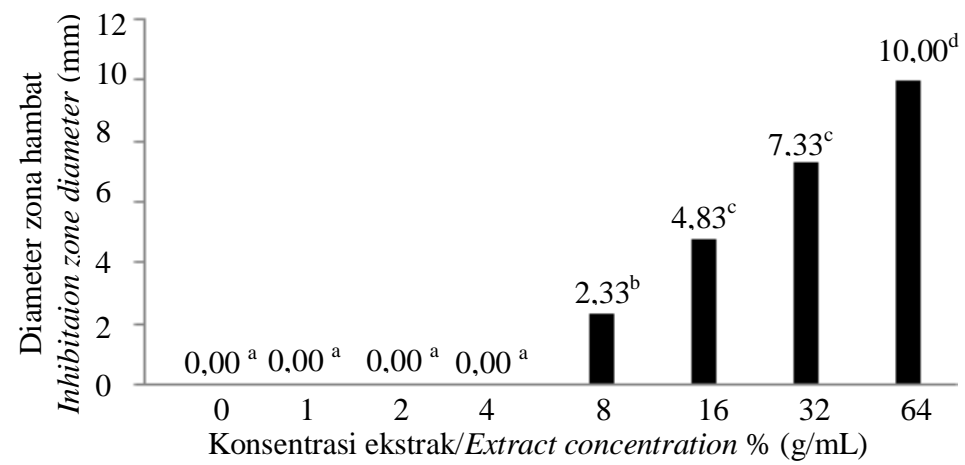

Gambar 5. Rerata diameter zona hambat dari ekstrak kulit buah kakao terhadap pertumbuhan bakteri $S$. aureus pada inkubasi 24 jam.

Figure 5. The mean diameter of inhibition zone of cacao pod husk extract on the growth of S. aureus at 24 hours incubation. 


\section{KHM ekstrak konsentrat kulit buah kakao}

Nilai KHM ekstrak kulit buah kakao terhadap bakteri $E$. coli, B. subtilis dan $S$. aureus dengan kerapatan $10^{8} \mathrm{CFU} / \mathrm{mL}$ yang diperoleh dalam penelitian ini berturut-turut sebesar $32 \%(\mathrm{~g} / \mathrm{mL})$, $16 \%(\mathrm{~g} / \mathrm{mL})$, dan $8 \%(\mathrm{~g} / \mathrm{mL})$. Tabel 1. Menunjukkan perbedaan aktivitas penghambatan dan KHM ekstrak konsentrat kulit buah kakao terhadap masing-masing bakteri uji. Perbedaan KHM tersebut dapat disebabkan oleh beberapa faktor, antara lain perbedaan jumlah populasi sel bakteri, struktur dinding sel masing-masing bakteri yang menyebabkan perbedaan kepekaan bakteri terhadap komponen senyawa aktif.

Populasi bakteri yang tinggi lebih sulit dihambat daripada populasi bakteri yang lebih rendah. Jumlah populasi $E$. coli paling tinggi dibandingkan dengan populasi $S$. aureus dan B. subtilis yaitu $7,2 \times 10^{8} \mathrm{CFU} / \mathrm{mL}$. Hal tersebut kemungkinan menyebabkan $E$. coli lebih sulit dihambat oleh senyawa aktif ekstrak kulit buah kakao terutama pada konsentrasi ekstrak yang rendah. Brooks (2001) menyatakan, bahwa semakin besar jumlah sel inokulum bakteri, maka semakin berkurang tingkat kepekaannya terhadap senyawa aktif. Konsentrasi sel untuk $B$. subtilis dan $S$. aureus masing-masing $1,1 \times 10^{8} \mathrm{CFU} / \mathrm{mL}$ dan $2,3 \times 10^{8} \mathrm{CFU} / \mathrm{mL}$, atau lebih kecil dibandingkan dengan konsentrasi $E$. coli. Hal ini dapat menyebabkan kedua bakteri ini lebih mudah untuk dihambat oleh senyawa aktif ekstrak kulit buah kakao, karena semakin kecil jumlah populasi inokulum bakteri maka akan semakin peka terhadap senyawa aktif.

E. coli merupakan bakteri Gram-negatif yang bersifat cenderung lebih resiten terhadap senyawa aktif, karena memiliki struktur dinding sel tipis yaitu sekitar 10-15 $\mu \mathrm{m}$ yang terdiri dari tiga lapisan yaitu membran luar, membran dalam dan lapisan peptidoglikan tipis di sebelah dalam dengan kandungan lipid yang tinggi (11-21\%). Lapisan bagian luar terdiri dari dua lapisan yaitu lipo- polisakarida dan lipoprotein (Hawley, 2003). Hal inilah yang kemungkinan menyebabkan senyawa bioaktif yang ada pada ekstrak konsentrat kulit buah kakao pada konsentrasi yang rendah tidak dapat menembus membran sel, sehingga tidak terjadi penghambatan pertumbuhan.

S. aureus dan B. subtilis merupakan bakteri Gram-positif yang struktur dinding selnya lebih sederhana. Dinding selnya tebal sekitar 25-30 $\mu \mathrm{m}$, berlapis tunggal dengan komponen terbesar terdiri dari peptidoglikan, dan dengan kandungan lipid yang rendah (1-4\%). Kelompok bakteri ini cenderung lebih rentan terhadap aktifitas komponen antibakteri seperti senyawa fenolik dan penisilin. Struktur dinding sel yang sederhana menyebabkan senyawa antibakteri mudah untuk masuk ke dalam sel dan menemukan sasaran untuk bekerja (Hawley, 2003).

Penelitian sebelumnya dalam pengujian aktivitas antioksidan dan antimikroba ekstrak kulit konsentrat buah kakao varietas Forastero, menunjukkan bahwa ekstrak kulit buah kakao mempunyai aktivitas antibakteri terhadap E. coli dan $S$. aureus. E.coli mempunyai sifat lebih peka terhadap senyawa aktif ekstrak. Pada penelitian tersebut, konsentrasi ekstrak yang diujikan adalah $5 \%$ (250 $\mu \mathrm{g} / \mathrm{disc}), 10 \%$ (500 $\mu \mathrm{g} / \mathrm{disc})$, dan $20 \%$ (1000 $\mu \mathrm{g} /$ disc) dengan menggunakan Dimetil sulfoksida (DMSO) sebagai pengencer ekstrak. Penghambatan bakteri terjadi pada semua konsentrasi ekstrak tersebut (Sartini et al., 2007). Aktivitas penghambatan bakteri yang berbeda ini kemungkinan disebabkan oleh perbedaan bahan pengencer dan varietas kakao yang digunakan. DMSO merupakan pelarut polar berspektrum luas, sehingga dapat melarutkan senyawa alkaloid dan flavonoid yang terkandung dalam kulit buah kakao. Sebaliknya pelarut akuades hanya dapat melarutkan senyawa bersifat polar. Elwers et al. (2009) melaporkan bahwa terdapat perbedaan kandungan senyawa polifenol antara kakao criollo, forastero dan trinitario/hibrida (kadar senyawa-senyawa

Tabel 1. Konsentrasi hambat minimum ekstrak kulit buah kakao, terhadap E. coli, B. subtilis, dan S. aureus.

Table 1. Minimum inhibitory concentration of pod cacao extrac against $\mathrm{E}$. coli, B. subtilis, and S. aureus.

\begin{tabular}{|c|c|c|c|c|c|c|c|c|}
\hline \multirow[t]{2}{*}{ Bakteri (Bacteria) } & \multicolumn{7}{|c|}{ Konsentrasi hambat minimum (\%) } & Minimum inhibitory consentration (\%) \\
\hline & 0 & 1 & 2 & 4 & 8 & 16 & 32 & 64 \\
\hline Escherichia coli & - & - & - & - & - & - & + & + \\
\hline Bacillus subtilis & - & - & - & - & - & + & + & + \\
\hline Staphylococcus aureus & - & - & - & - & + & + & + & + \\
\hline
\end{tabular}

Keterangan/Note $:+$ berarti terdapat zona hambat (there are inhibiton zone)

- berarti tidak terdapat zona hambat (there are no inhibiton zone) 
fenolik dari total kandungan polifenol kakao). Lebih lanjut Irmalia (2011) melaporkan, bahwa varietas forastero memiliki kandungan antosianin yang tidak ditemukan pada varietas kakao yang lain. Hal tersebut menunjukkan bahwa setiap varietas kakao memiliki perbedaan akumulasi metabolit sekunder, yang kemungkinan dapat menyebabkan perbedaan aktivitas antibakteri antara varietas forastero dengan varietas hibrida.

Hasil penelitian memiliki implikasi yang sangat penting dalam pengembangan IPTEK baik yang menyangkut buah kakao itu sendiri maupun yang menyangkut kesehatan manusia dan lingkungan. Hal yang terkait dengan buah kakao adalah memberikan jawaban ilmiah atas pertanyaan mengapa yang menyerang buah kakao di lapangan bukan bakteri tetapi jamur. Hal yang terkait dengan kesehatan manusia adalah hasil penelitian ini menunjukkan bahwa ektrak kulit buah kakao berpotensi sebagai sumber bahan pengawet makanan yang aman dan terbarukan.

\section{Kesimpulan}

Ekstrak konsentrat kulit buah kakao hibrida mempunyai potensi sebagai bahan antibakteri terhadap E. coli, B. subtilis, dan S. aureus. Ekstrak konsentrat kulit buah kakao paling efektif menghambat pertumbuhan $S$. aureus dengan konsentrasi hambat minimum (KHM) $8 \%(\mathrm{~g} / \mathrm{mL})$, jika dibandingkan dengan bakteri B. subtilis dan E. coli dengan KHM berturut-turut sebesar $16 \%(\mathrm{~g} / \mathrm{mL})$ dan $32 \%(\mathrm{~g} / \mathrm{mL})$.

\section{Daftar Pustaka}

Adamafio NA, IK Afeke, J Wepeba, EK Ali \& FQ Quaye (2004). Biochemical composition and in vitro digestibility of cocoa (Theobromae cacao) pod husk, cassava (Manihot esculenta) peel and plantain (Musa paradisiacal) Peel Ghana J Sci 44, 29-38.

Alemawor F, F Victoria, P Dzogbefia1, EOK Oddoye \& JH Oldham (2009). Effect of Pleurotus ostreatus fermentation on cocoa pod husk composition: Influence of fermentation period and $\mathrm{Mn} 2+$ supplementation on the fermentation process. African J Biotech 8(9), 1950-1958.

Andrews JA (2006). Determination of Minimum Inhibitory Concentrations. Birmingham, Department of Microbiology, City Hospital NHS Trust.

Anggriani R (2010). Karakterisasi simplisia dan isolasi senyawa antosianin dari bunga tanaman pacar air (Impatiens balsamina Linn.) berwarna merah. Skripsi. Fakultas Farmasi Universitas Sumatera Utara. Medan.
Anonim (2010). Outlook Komoditas PertanianPerkebunan. Jakarta, Pusat Data dan Informasi Pertanian, Kementerian Pertanian.

Arifin H, N Anggraini, D Handayani \& R Rasyid (2006). Standarisasi ekstrak etanol daun Eugenia cimini Merr. J Sains Tek. Far 11(2), 88-92.

Brooks GF, JS Butel \& SA Morse (2001). Jawetz, Melnick, and Adelberg's: Mikrobiologi Kedokteran. Alih Bahasa: Bagian Mikrobiologi Fakultas Kedokteran UNAIR. Salemba Medika, Jakarta.

Dahlan S (2004). Statistika untuk Kedokteran dan Kesehatan. Jakarta, PT Arkans.

Das K, RKS Tiwari \& DK Shrivastava (2010). Techniques of evaluation of medicinal plant products as antimicrobial agent: current methods and future trends. Jof Medicin Plants Res, 4(2), 104-111.

Elwers S, A Zambrano, C Rohsius \& R Lieberei (2009). Differences between the content of phenolic compounds in criollo, forastero and trinitario cocoa seed (Theobroma cacao L.). Eur Food Res Technol 229, 937-948.

Goeswin A (2007). Teknologi Bahan Alam. Bandung, ITB. 166p.

Hanafiah KA (2001). Rancangan Percobaan Teori dan Aplikasi. Jakarta, PT Raja Grafindo Persada. 238p.

Harsini T \& Susilowati (2010). Pemanfaatan kulit buah kakao dari limbah perkebunan kakao sebagai bahan baku pulp dengan proses organosolv. J Ilmiah Teknik Lingkungan 2 (2), 80-89.

Hawley LB (2003). Intisari Mikrobiologi dan Penyakit Infeksi. Alih Bahasa: Brahm U. Pendit. Jakarta, Hipokrates.

Helmenstein AM (2010). Theobromine Chemistry: Theobromine is Chocolate's Caffeine Relative. Taken from [http://chemistry.about.com/od/ facts structures/ a/theobrominechemistry.htm], 6 Mei 2010.

Irmalia WR (2011). Daya Antibakteri Ekstrak Biji Coklat (Theobroma cacao) Varietas Forastero terhadap Streptococcus mutans. Skripsi. Fakultas Kedokteran Gigi, Universitas Airlangga.

Kusumawati N, BSL Jenie, S Setyahadi, RD Haryadi (2003). Seleksi bakteri asam laktat indigenus sebagai galur probiotik dengan kemampuan menurunkan kolesterol. J Mikrobiol Ind 8(2), 39-43.

Matsumoto M, M Tsuji, J Okuda, H Sasaki, K Nakano, K Osawa, S Shimura \& T Ooshima (2004). Inhibitory effects of cacao bean husk extract on plaque formation in vitro and in vivo. Eur J Oral Sci 112 (3), 249-52.

Pratiwi ST (2008). Mikrobiologi Farmasi. Jakarta, Penerbit Erlangga. 
Prescott LM, JP Harley \& DA Klein (2005). Microbiology, Sixth Edition. New York, Mc GrawHill.

Sartini, MN Djide \& G Alam (2007). Ekstraksi Komponen Bioaktif dari Limbah Kulit Buah Kakao dan Pengaruhnya Terhadap Aktivitas Antioksidan dan Antimikroba. Diunduh dari: [http://mot.f armasi. ugm.ac.id/files/18kulitaacao_PakAlam.pdf], 22 Juni 2011
Sudirja R, MA Solihin \& S Rosniawaty (2007). Respon beberapa sifat kimia fluventic eutrudepts melalui pendayagunaan limbah kakao dan berbagai jenis pupuk organik. Soil Rens J 8(6), 23-30.

Talaro KP (2002). Foundations in Microbiology Fourth Edition. New York, Mc Graw Hill. 